\title{
Review Paper: The Fundamentals of Biochar as a Soil Amendment Tool and Management in Agriculture Scope: An Overview for Farmers and Gardeners
}

\author{
Tawheed Mohammed Elhessin Shareef ${ }^{1,2^{*}}$, Baowei Zhao ${ }^{1}$ \\ ${ }^{1}$ School of Environmental and Municipal Engineering, Lanzhou Jiaotong University, Lanzhou, China \\ ${ }^{2}$ Department of Agriculture Engineering, Faculty of Agriculture, University of Khartoum, Khartoum, Sudan \\ Email: *toota.eng@gmail.com
}

How to cite this paper: Shareef, T.M.E. and Zhao, B.W. (2017) Review Paper: The Fundamentals of Biochar as a Soil Amendment Tool and Management in Agriculture Scope: An Overview for Farmers and Gardeners. Journal of Agricultural Chemistry and Environment, 6, 38-61.

https://doi.org/10.4236/jacen.2017.61003

Received: November 22, 2016

Accepted: December 25, 2016

Published: December 28, 2016

Copyright $\odot 2017$ by authors and Scientific Research Publishing Inc. This work is licensed under the Creative Commons Attribution International License (CC BY 4.0).

http://creativecommons.org/licenses/by/4.0/

\begin{abstract}
Improving the soil and biomass with coal is estimated at the international level as a way to enhance soil productiveness, fertility and also to mitigate climate change. Biochar employed to improve land scope and impound carbon, is attracting a great deal of attention. Its characteristics of chemical, physical and biological properties, containing big surface area, CEC (Cation Exchange Capacity), high water-holding capacity, size of pore, volume, distribution, and element composition, affect its recognized influences, particularly on microbial communities. These are discovered in the agriculture lands, lands remediation and composting. However, incomplete information existed about biochar for several farmers or peasants in agriculture scope. Therefore, farmers or peasants and gardeners are facing new opportunities and defiance each day, from feeding global extending and expanding population, whilst meeting severe new emissions requirements, to create more food on fewer land area while reducing their environmental emissions. Widespread application and utilization of biochar in agricultural scope, forestry production, energy, environmental protection and additional areas, has interested awareness by scientists and investigators inside and/or outside the country. The objective of this paper is to provide a guide for the farmers or peasants and gardeners with an essential information about biochar and what the ability of biochar can be achieved in the soil, and which can provide the scientific reference for the biochar application, and to get high yield and good quality of crops in all of different soils.
\end{abstract}

\section{Keywords}

Biochar, Pyrolysis Methods, Agricultural Advantages, Environmental Impacts 


\section{Introduction}

Agriculture has to address at the same time three intertwined challenges: ensuring food safety through increased income and productivity, adapting to climate change and contributing to climate change mitigation [1] [2] [3] [4] [5].

This challenge, worsening global pressure on normal resources, mainly on water, will need essential changes in our food classifications. To treat these challenges, feeding systems have to be simultaneously, additional effective and flexible, at each level from the farm to the worldwide level. They have to develop more effectively in reserve employment and become more capably to adapt to variations and impacts. For example in 1990s, livestock and cultivation increasing were the most important sources to make living in the Sudan for nearly $61 \%$ of the working inhabitants [6] [7]. More than one third of the overall area of Sudan is appropriate for agricultural improvement and development. Therefore, it is necessary to inform the farmers or peasants of the importance of biochar to improve soil and increase productivity by improving water and nutrient retention [8].

The motivation to study biochar came from the soil possibility to remedy many of the challenges fronting the today's world: waste administration, renewable energy, soil declination, and climate change. Different several other stages for the extraction renewable energy from feedstocks, biochar build up soil fertility and food availability rather than act as a challenging benefit. If suitably understood and applied, biochar has the possibility for generating several dissimilar win conditions with a few disadvantages [9].

The concept to use biochar as a soil amendment may seem recent but it really comes from the study of very ancient soils in the Basin of Amazon. It is known that "Terra preta de Indio", or "black soil of the Indians" was designed by indigenous peoples since thousands of years ago when they amassed charcoal and a different wastes, nutrient trash like animal bones and fish bones [10] [11] [12].

Until today, black soil or "Terra preta" soils remain more fertile than neighbouring or surrounding, unmodified soil. Researchers see that the biochar in these soils, is the one that keeps them so fertile over such extensive stages in an environment that rapidly filters nutrients out of soil and where organic materials decomposes so quickly [11] [12].

\section{Biochar}

The definition of biochar it is the carbon products, gained while the raw materials, like forest, animal compost, and plant residues, is heated in a closed storage place without air. in many technical and clearer standards, biochar is created by seeming thermal decomposition of organic substance below incom- plete supply of $\left(\mathrm{O}_{2}\right)$ oxygen, and at comparatively low temperature $\left(<700^{\circ} \mathrm{C}\right)$. [13].

The feedstock's heats up to the point at which pyrolysis starts. At this point, the reaction becomes exothermic, that means it starts to create heat and no longer consumes it [11] [12]. The expression "Biochar" is a moderately contemporary 
improvement, evolving in combination with soil managing, carbon confiscation or sequestration matters, and immobilization of contaminants [14].

The properties of biochar can change extensively, depending on what the biochar is prepare from and how it is complete. Some biochars can have characteristics which make them an excellent amendment in one soil but not another or the biochar can be simple awful [12]. Peasants or farmers must be aware of this, and this paper addresses the variability in biochar materials. Biochar retains the formation or structure of the biomass and can be very porous with a very great surface area; according to previous study SEM micrographs of Biochar CS (cotton (Gossypium herbaceum) straw) and Biochar PS (potato (Solanum tuberosum) straw), the structure porous of biochar shown in Figure 1 [15].

\section{Power of Biochar}

Powerful of biochar it's attention-grabbing because it has been established and demonstrated to progress crop outgrowth and quality of soil, while confiscating or sequestering $\mathrm{C}$ in soil and providing other environmental advantages. As such, it represents a tool management for quality of soil on the long period, with climate change mitigation. Presently, scientific of research, on the environmental advantages and agricultural scope of biochar is being published at growing rate. However, biochar is the main ingredient in a new carbon-negative strategy to resolution numerous critical current ecological, economic and energy defies. If properly made and used, biochar can relieve climate change and other environmental effects: 1) Rise soil fertility \& agricultural yields; 2) sequester carbon; 3 ) enhance soil structure, water penetration \& aeration; 4) decrease use of pesticides and synthetic fertilizers; 5) reduce methane emission from soil and nitrous oxide; 6) decrease farm chemicals leaching into watersheds and nitrate; 7) create or Produce renewable fuels from feedstock's; 8) change green $\&$ brown residues into valuable resources; 9) decrease dependence on imported oil; 10) support local, distributed energy production and distribution; 11) increase energy security and community food; 12) construct local jobs and economic cycles.
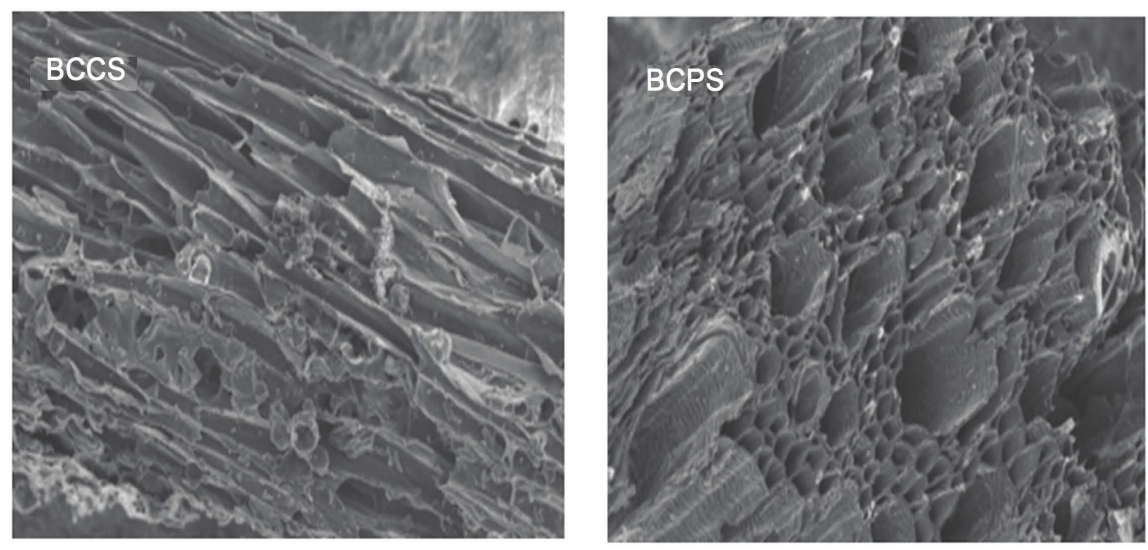

Figure 1. Show the porous structure of biochar (Photomicrograph from Scanning Electron Microscopy (SEM)) [15]. 


\subsection{Agricultural Advantages}

In a lot of pot and field studies, biochar has been shown to get better crop yields when compared to suitable controls where biochar was not applied. Representative results from short-term studies are presented in Table 1. Biochar has caused in very high yield enhancements on very meagre or poor soils such as acidic humid and tropical soils, in some instance increasing yields by factors of two or more. In more fertile soils, more modest developments in the range of $10 \%$ are common. Biochar does not comprise any appreciable quantities of existing nitrogen, but does comprise some decomposable carbon [10] [11]. So, if biochar is applied and deficient nitrogen is supplied, nitrogen immobilization can happen and decrease crop yields. This also occurs with compost, for example: if the ratio of carbon to nitrogen $(\mathrm{C}: \mathrm{N})$ is too high. Biochar is a soil improvement that is to be used along with applicable sources of nutrients, like animal composts, green manures, composts and fertilizers. It is not a replace for these inputs. Though the ash in biochar fixes improves nutrients to plants, several biochars comprise only small quantities of ash. Also, any nutrients in ash not used by plants in the year after application are finally lost from the soil, sometimes quickly, for example by leaching.

Table 1. Agricultural influences of biochar.

\begin{tabular}{|c|c|c|c|c|c|c|c|}
\hline Crop & $\begin{array}{c}\text { Experimental } \\
\text { Type }\end{array}$ & Soil & Region & Biochar & $\begin{array}{l}\text { Application } \\
\text { Rate }\end{array}$ & Effect & Authors \\
\hline $\begin{array}{l}\text { Cherry, } \\
\text { tomato }\end{array}$ & Pot & Chromosol & Australasia & $\begin{array}{l}\text { Wastewater sludge } \\
\text { pyrolysed at } 550^{\circ} \mathrm{C}\end{array}$ & 10 ton/ha & $64 \%$ & {$[116]$} \\
\hline $\begin{array}{l}\text { Wheat, } \\
\text { Soybean, } \\
\text { Radish }\end{array}$ & & $\begin{array}{l}\text { Ferrosol \& } \\
\text { Calcerosol }\end{array}$ & Australasia & $\begin{array}{l}\text { Pyrolysed paper } \\
\text { grindery waste }\end{array}$ & 10 ton/ha & $\begin{array}{l}\text { Up to } 225 \% \text { rise in biomass } \\
\text { production (soybean only: } \\
\text { negative responses for } \\
\text { wheat and soybean). }\end{array}$ & [115] \\
\hline $\begin{array}{c}\text { Rice } \\
\text { (Oryza sativa } \\
\text { L., cv } \\
\text { Wuyunjing 7) }\end{array}$ & Field & & China & & $10 \& 40$ ton $/ \mathrm{ha}$ & $\begin{array}{l}\text { Increase in rice yield of up to } \\
14 \% \text { in highest application rate } \\
\text { and in the absence of applied } \mathrm{N} \text {. }\end{array}$ & [117] \\
\hline Maize & Pot & Ultisol & China & $\begin{array}{l}\text { Rice straw, pyrolysed } \\
\text { at } 250^{\circ} \mathrm{C}-400^{\circ} \mathrm{C} \\
\text { for } 2-8 \text { Hours. }\end{array}$ & $1 \% \pm \mathrm{NPK}$ & $\begin{array}{l}\text { Increased maize yield of } \\
146 \% \text { in the presence of NPK } \\
\text { and } 64 \% \text { in its absence. }\end{array}$ & [118] \\
\hline Maize & Pot & $\begin{array}{c}\text { Top soil \& } \\
\text { subsoil }\end{array}$ & $\begin{array}{c}\text { South } \\
\text { America }\end{array}$ & $\begin{array}{l}\text { sugarcane, } \\
\text { bagasse }\end{array}$ & $\begin{array}{c}50 \mathrm{~g} \mathrm{~kg} / \mathrm{soil} \\
+/ \text {-bio digest } \\
\text { waste }(100 \mathrm{kgN} \\
/ \mathrm{ha})\end{array}$ & $\begin{array}{l}\text { Biochar improved green biomass } \\
\text { growing of maize in top soil } \\
\text { non-attendance and attendance } \\
\text { of waste. Biochar increased } \\
\text { green biomass in presence } \\
\text { of effluent in subsoil. }\end{array}$ & [119] \\
\hline Maize & Field & $\begin{array}{l}\text { Degraded } \\
\text { Amazonian }\end{array}$ & $\begin{array}{l}\text { South } \\
\text { America }\end{array}$ & & & Biochar doubled maize yield. & [120] \\
\hline Radish & Pot & Alfisol & Australasia & $\begin{array}{c}\text { Poultry litter, } \\
\text { pyrolysed at } \\
450^{\circ} \mathrm{C} \text { and } 550^{\circ} \mathrm{C}\end{array}$ & $\begin{array}{c}0-50 \mathrm{ton} / \mathrm{ha} \\
+/-100 \mathrm{~kg} \mathrm{~N} / \mathrm{ha}\end{array}$ & $\begin{array}{c}(+42 \%) \text { at } 10 \text { ton/ha without } \mathrm{N} \\
(+96 \%) \text { at } 50 \text { ton/ha without } \mathrm{N} \\
\text { with } \mathrm{N} \text {, lower temp } \\
\text { material more effective. }\end{array}$ & [121] \\
\hline $\begin{array}{l}\text { Radish } \\
\text { (Raphanus } \\
\text { sativus) }\end{array}$ & Pot & Alfisol & Australasia & $\begin{array}{c}\text { Green waste, } \\
\text { pyrolysis }\end{array}$ & $10-100$ ton/ha & $\begin{array}{l}\text { At highest rates with nitrogen } \\
\quad\left(100 \mathrm{~kg} \cdot \mathrm{ha}^{-1}\right) \text { application, } \\
+280 \% \text { yield, compared to } \\
+95 \% \text { in absence of biochar. }\end{array}$ & [122] \\
\hline
\end{tabular}


Then how does biochar enhance crop yields? Yield improvements with biochar have been qualified to the following effects: 1) Increase in $\mathrm{pH}$, the $\mathrm{pH}$ of biochar is often high (e.g. >9). This is beneficial in soil were the $\mathrm{pH}$ is lesser than optimal for the intended use, but not if the $\mathrm{pH}$ is higher than best; 2) Immediate or direct addition of nutrients. Ash in biochar contributes some nutrients to soil, but this is a short-term effect; 3) Retention of nutrients substances. With the passing of time, biochar surfaces advance an ability to retain nutrients in soil. This is a lengthy -period advantage of biochar and sets it apart from other forms of biological materials in soil, which also help retain nutrients but decompose relatively quickly; 4) Potential improvement of soil physical properties. Biochar has an extremely low density \& highly porous; 5 ) Biochar may provide suitable situations for advantageous microbes soil, for example $\mathrm{N}$-fixing Rhyzobia and Mycorrhizal fungi [10] [11]. Table 2 shows crop yield variations when applying biochar. [16] is also from Table 2. Corn yield improved after addition dissimilar varieties of biochar. The increase amount yield of crop depended on the quantity and types of additional biochar. Dissimilar biochar had dissimilar influence on dissimilar crops [16]. In short, biochar has the potential to provide or supply profits for quality of soil both on the short and long term. But on the other hand, biochar amelioration unhelpful permanently in agricultural production regardless of the biochar to be a high degree of carbon material with unparalleled properties. possibility disadvantages attached to biochar, soil contain: 1) Oversupply of nutrients; 2) Binding nutrients in soil); 3) Rise in $\mathrm{pH}$ and soil Electrical Conductivity EC; 4) effect on growth and soil bioprocesses; 5) liberation of toxicants [17].

\subsection{Composting with Biochar}

Biochar is firm substance achieved with organized carbonization of feedstock's. Prepared biochar is a constant form of a hard black material (charcoal) that has several of the helpful characteristics of activated charcoal, at a modest price, and a beneficial product for positive manure or compost operators. Excellent aera-

Table 2. Crop yield variations when applying biochar.

\begin{tabular}{cccc}
\hline Types of biochar & Biochar addition amount $\left(\mathrm{t} / \mathrm{hm}^{2}\right)$ & Crop species & Effect \\
\hline SFWB & $11 \mathrm{~g} / \mathrm{kg}$ soil & Rice crop & $\begin{array}{c}\text { A lone with biochar has no evident influence, but } \\
\text { rate production improved by } 80 \% \text { with mineral fertilizer }\end{array}$ \\
BB & $0.5 \mathrm{~g} / \mathrm{kg}$ soil & Soybean crop & Feedstock of unit area improved by $51 \%$ \\
RHB & $10 \mathrm{~g} / \mathrm{kg}$ soil & Corn crop, Soybean crop & rate production improved by $10 \%-40 \%$ \\
CCB & $0.45 \mathrm{~g} / \mathrm{kg}$ soil & Corn crop & Yield improved by $10.98 \%$ \\
BBC & $20 \mathrm{~g} / \mathrm{kg}$ soil & Corn crop & Yield improved by $22.77 \%$ \\
BBC & $40 \mathrm{~g} / \mathrm{kg}$ soil & Corn crop & Yield improved by $49.80 \%$ \\
PMSB & $10 \mathrm{~g} / \mathrm{kg}$ soil & Wheat crop & Acid soil yield improved by $30 \%-40 \%$ \\
CSB & $10 \mathrm{~g} / \mathrm{kg}$ soil & Wheat crop & Yield improved by $21.89 \%$ \\
\hline
\end{tabular}

${ }^{\star}$ SFWB $=$ Secondary Forest Wood Biochar, BB $=$ Branch Biochar, RHB $=$ Rice husks biochar, CCB $=$ Corn Cob Biochar, BBC $=$ Biological Black Carbon, $\mathrm{PMSB}=$ Paper Mill Sludge Biochar, CSB $=$ Corn Stover Biochar. 
tion, compost organization and hard non-pile configuration are well recognized and applied methods to fertilizer odor manage.

Biochar is an operative adding to existing greatest practices for these kinds of manure odors [18]. Biochar decreases smells from volatile oily acids [19] [20]. $\mathrm{NH}_{3}$ (Ammonia) and $\mathrm{N}$ (nitrogen) smells or odors (both in the first and last stages of composting) [21] [22]. Lab studies point out that biochar decreases $\mathrm{H}_{2} \mathrm{~S}$ (Hydrogen Sulfide) and S (Sulfur) founded odors [22] [23]. Field area studies by $10 \%$ biochar shows $\mathrm{CH}_{4}$ (methane) decrease by $1 / 3$ [24].

\subsection{Environmental Benefits and Impacts}

Many studies have found that biochar stays in soil for centuries to millennia. This is because the mass of the material is extremely resistant to decomposition by microbes. Throughout pyrolysis, the structure of molecular biomass is reorganized, to a form that is extremely constant in soil. Carbon that was in the atmosphere gets combined into biomass by plant wastes, plants are pyrolyzed, and biochar placed in soil. Thus biochar can be employed as an instrument to sequester or seize carbon in soil in a safe system. Not just is there no possibility that the carbon in biochar will suddenly "escape or leak" back into the atmosphere, but having biochar in soil also offers advantages in terms of quality of soil.

Biochar can offer additional environmental advantages, containing: 1) Decrease nutrient pollution in water bodies; 2) Biochar may decrease the production of greenhouse gases by soil; 3) Impacts of biochar on the bio-availability and movement of heavy metals have been extensively reported [25] [26] [27] [28]. So biochar can decrease the bio-availability and mobility of pesticides and heavy metals in soil [11] [12]. Biochar can be a Straightforward yet vigorous tool to fight climate change. As biological materials decompose, gases of greenhouse, such as carbon dioxide (CO2) and $\mathrm{CH}_{4}$ (methane), are released into the atmosphere. Through carbonizing the biological sustenance, a lot of the carbon (C) becomes "steady" into additional unchanging constant form, and when the outputting biochar is applying to soils, (C) carbon is efficiently isolated or sequestered [29]. It is assessed that employ of this technique to "tie up" (C) carbon has the possibility to decrease current universal carbon releases or emissions by more than $10 \%[30]$.

\section{Generation of Charcoal or Biochar}

Charcoal or biochar is generated by heating organic substance under conditions of incomplete oxygen [31]. Biochar is generated via heating biological substance below conditions of incomplete oxygen. There are several methods to attain this result. The varieties of feedstock or organic substance that is employed and the conditions below which a biochar is created extremely affect its relative quality as a soil improvement [32] [33]. Biochar are made from range of biomasses that have dissimilar chemical \& physical properties as the original biomass can be subjected to a collection of analyses with a view to supply the essential physico- 
chemical properties of every raw and pyrolyzed material. These chemical and physical characterizations are showed in Figure 2.

The properties of each biomass feedstock are significant in thermal conversion processes, mainly the proximate examination or analysis (moisture content \& ash), caloric value, portions of fixed carbon, and volatile ingredients [34]; percentage of lignin, cellulose, and hemicelluloses [35]; percentage and composition of inorganic substance, mass, true density, particle size, and moisture content.

Wide feedstock's have been used in the production of biochar [34], such as bio energy crops (willows, miscan thus, and switch grass) [36] [37], forest residues (sawdust, grain crops, and nut shells) [38], organic waste (green yard waste and animal manure) [39] [40], agricultural waste [41]-[46], kitchen waste, and sewage sludge [47].

In all cases, biochar makers should strive to protect their own health and that of the environment by guaranteeing they make biochar in a fresh or clean and safe method. Some traditional ways of making charcoal, for example in earthen hills, are not safe and are poorly effective. Indeed, they produce large amounts of smoke which represents a health risk and is an environmental pollutant, and one obtains only small amounts of biochar from the initial biomass [48].

\subsection{Physico-Chemical Characterisation of Biochar}

Anaerobic thermal transformation of feedstock can be completed in three dissimilar processes: gasification; liquefaction and pyrolysis or carbonization. Altogether give outputs in 3 stages: a) solid; b) liquid; c) gas, with the product composition dependent on procedure situations. Therefore, pyrolysis is distinguished by long residence times and temperate temperatures, liquefaction happens beneath high heating rates, however gasification is defined by great temperatures, regularly with additional, though sub-stoichiometric, oxygen. Pyrolysis typically creates a solid, organized or structured, carbonaceous sub-

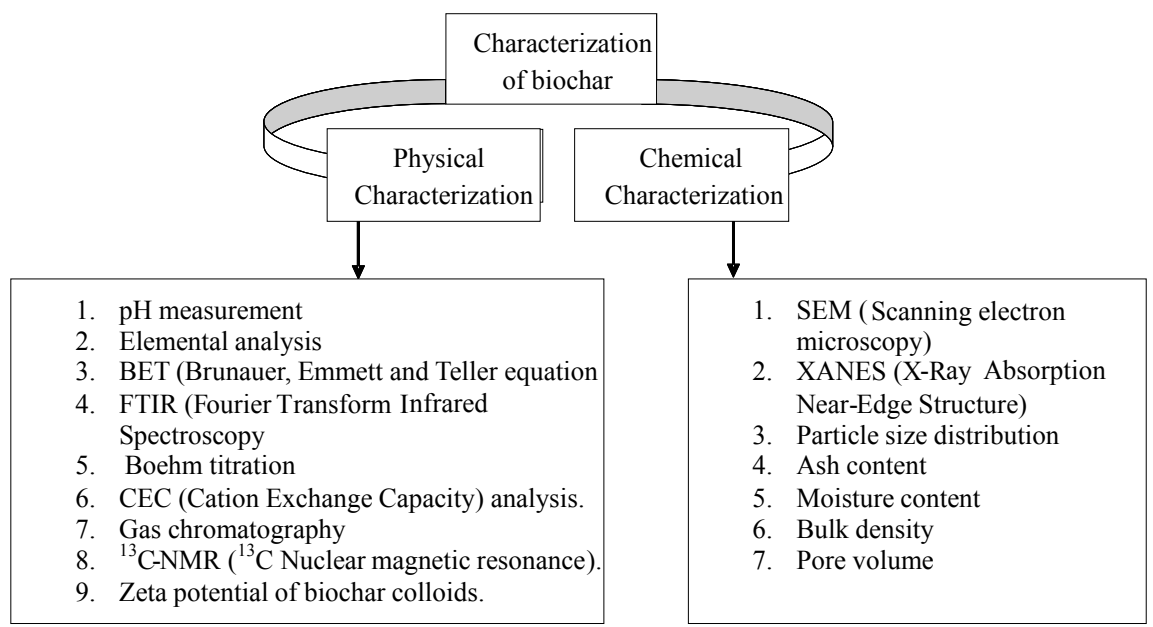

Figure 2. Show the outline of proposed characterization of biochar including physical and chemical characterization. 
stance which, compared to the biomass, displays a great surface area [49], decreased oxygen \& hydrogen content [50], and a concentration of nutrients [51] [52].

Main properties of biochar, like (SA) surface area, $\mathrm{pH}$, ash, (BD) bulk density, volatiles, (WHC) water holding capacity and (PV) pore-volume, are sensitive purposes of pyrolysis biomass and procedure conditions. Surface area is easily noticeable through classical adsorption mechanisms, such as nitrogen adsorption investigated by the (BET) Brunauer-Emmett-Teller, adsorption isotherm [53] [54], whilst proximate analysis offers quantification of fixed carbon, volatile and residual ash [55]. Some previous studies for example, assessments by [56] [57] recapitulated the impact of pyrolysis temperature on these characteristics and consequent interactions in soil.

The chemical environment of the fixed carbon can be investigated or probed by a diversity of solid phase C13 nuclear magnetic resonance mechanisms or techniques [58] [59] [60]. Biochar chemistry and surface functionality can be evaluated by different methods and techniques including spectroscopically by vibrational techniques such as infrared [58] [59], electron energy loss [61] spectroscopies and titrimetrically [62]. Such examinations establish that biochar properties are a difficult purpose of biomass nature and pyrolytic situations. Both quantity or mass yield and the grade of aromaticity are purposes or functions of pyrolysis conditions and biomass. Temperature, sweep gasstream rate, feedstock particle size and heating rate, are all factors that touch the mass yield of biochar. [63] explored the effect of heating rate; maximum treatment temperature and sweep gas flow rate in a 23 factorial scheme trial and found that temperature was the leading parameter. Comparable or similar temperature- induced yield reductions have been stated for pyrolysis of animal wastes [64] [65], sunflower cake [66], rapeseed [67], cottonseed cake [68], pinewood bark [69], and sugarcane bagasse [70]. Increased heating rate, increased sweep gas streamor flow rate and reduced particle size all lead to reduced biochar production [71]. This shows that reaction yield is ruled by reaction kinetics, mass transfer considerations and thermal.

Temperature [59] and time at temperature [72], rise the extent of aromatic construction creation in biochar. Aromaticity is a significant factor of biochar quality in specific situations. Little aromaticity and minor aromatic cluster size infers great surface functionality compared to substance characterized by greater aromatic areas, and leads to greater cation exchange capacity in soil [73]. This contrasts the increased water holding capacity of raised temperature material due to upper or higher surface area.

On the other hand, a rise in biochar aromaticity leads to greater resistance or recalcitrance in soil with concomitantly extended sequestration potential. Also, great temperature biochar exhibits high surface area and porosity, both of which can be exploited in adsorption-based remediation technologies. Just as pyrolysis conditions time alter the properties of the biochar, so too does the feedstock.

Biochar have been created by pyrolysis of wastes or residues of rapeseed [74], rape \& sunflower [75] beneath an assortment of temperatures and heating rates, 
whereas agricultural residues of relevance in a Turkish have been studied extensively [63] [76] [77]. As well, pyrolysis of sewage sludge has been presented to create a best quality of biochar [78] [79] whereas casein [80] gives an extremely porous product (content of porosity $=20 \%$ ) using a high nitrogen content $(9.02 \% \mathrm{w} / \mathrm{w})$. Even microalgae have been proved to create great yields $(>1 / 3$ by mass) [81]. In addition to traditional pyrolysis procedures for biochar generation, alternate methods have been discovered. Comprises: 1) pressurized pyrolysis [82]; 2) hydrothermal carbonization [83] [84] [85]; 3) microwave pyrolysis [86]. These latter procedures have potential as ways to resources with properties external the range of usual pyrolysis products and greater energy efficiency.

\subsection{Pyrolysis Methods of Preparation Biochar}

Production and preparation of biochar distributed to pyrolysis, microwave carbonization technique and hydrothermal carbonization technique according to the dissimilar techniques of heating [48]. Figure 3 shows the process of preparation biochar. Therefore, Pyrolysis methods used to operation raw materials can be classified, to four kinds: a) slow; b) fast; c) flash and d) gasification pyrolysis methods. Table 3 shows the types of pyrolysis techniques. All types vary in expressions of modifications to structure of raw material (feedstock's), temperatures \& heating rates, that outcome in the production of various quantities of every product (like biochar, biooil \& syngas) [87] [88].

Various feedstock's and a large device (reactors) are utilized to make biochar through pyrolysis. Usually employed reactors contain: bench scale fixed bed, well swept fixed bed, fluidized bed and auger vertical tubular kinds [89]. An ex-

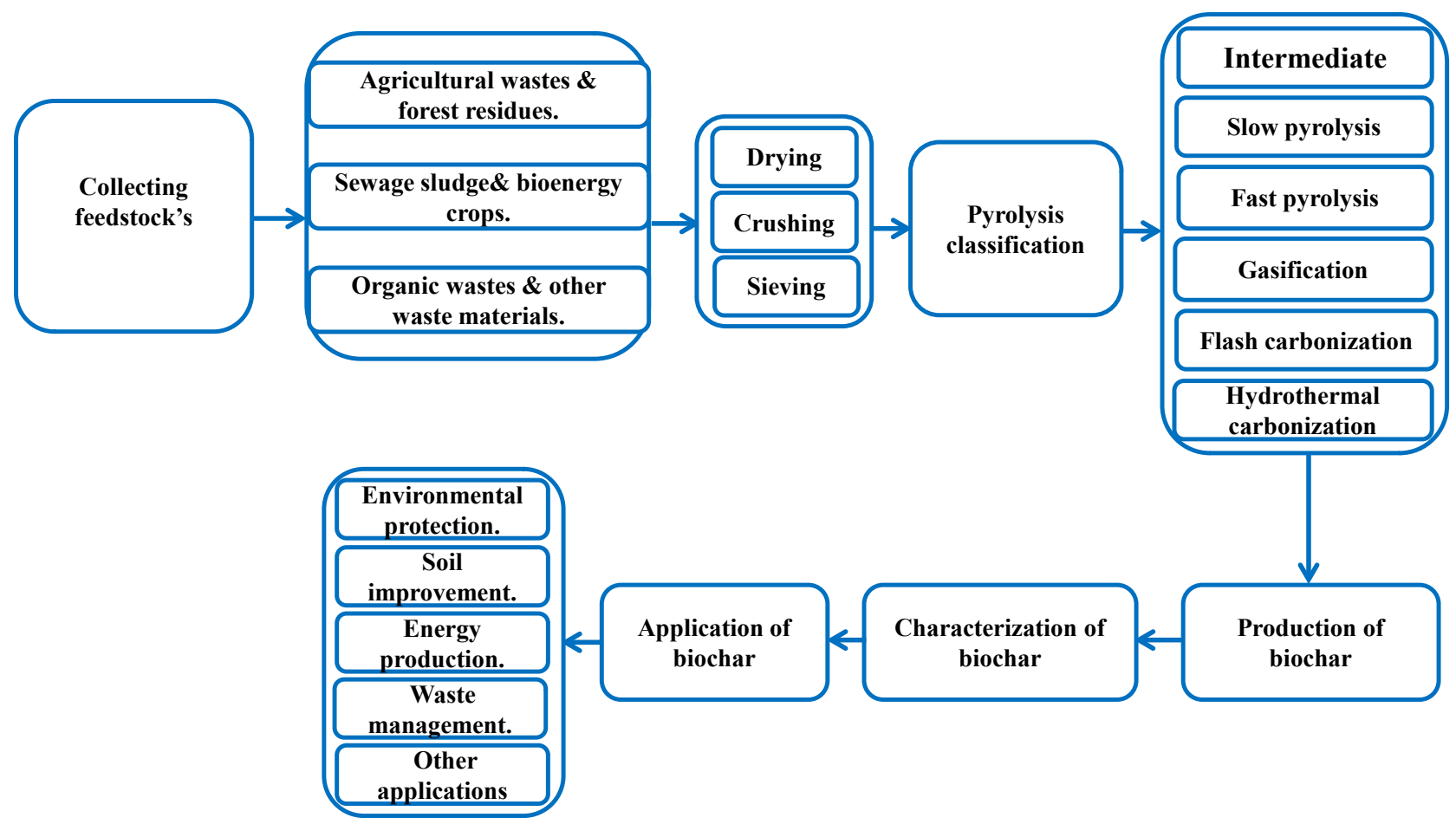

Figure 3. Show the process flowchart for the production of biochr. 
Table 3. Feedstock products under different kinds of pyrolysis methods.

\begin{tabular}{|c|c|c|c|c|}
\hline $\begin{array}{l}\text { Pyrolysis } \\
\text { methods }\end{array}$ & The main reaction conditions & $\begin{array}{l}\text { The liquid products } \\
\text { (TAR) }\end{array}$ & $\begin{array}{l}\text { Gas products } \\
\left(\mathrm{CH}_{4}, \mathrm{CO}, \mathrm{H}_{2}\right)\end{array}$ & $\begin{array}{l}\text { Firm product } \\
\text { (biochar) }\end{array}$ \\
\hline Slow method & $\begin{array}{l}\text { Not rising temperature }\left(400^{\circ} \mathrm{C}-660^{\circ} \mathrm{C}\right) \text {, not rising heating } \\
\text { rate }\left(0.1-1^{\circ} \mathrm{C} / \mathrm{S}\right) \text {, Gas or vapor residence time }(5-30 \mathrm{~min})\end{array}$ & $30 \%$ and $70 \%$ Wood vinegar & $35 \%$ & $35 \%$ \\
\hline $\begin{array}{l}\text { Medium speed } \\
\text { pyrolysis }\end{array}$ & $\begin{array}{l}\text { Not rising temperature }\left(400^{\circ} \mathrm{C}-550^{\circ} \mathrm{C}\right) \text {, Modest heating } \\
\text { rate }\left(10-200^{\circ} \mathrm{C} / \mathrm{S}\right) \text {, Gas or vapor residence time }(10-20 \mathrm{~S})\end{array}$ & $50 \%$ and $50 \%$ Wood vinegar & $25 \%$ & $25 \%$ \\
\hline Fast pyrolysis & $\begin{array}{l}\left.\text { Middle temperature (about } 500^{\circ} \mathrm{C}\right) \text {, Fast heating rate } \\
\qquad\left(1000^{\circ} \mathrm{C} / \mathrm{S}\right) \text { Vapor residence time }(<2 \mathrm{~S})\end{array}$ & $75 \%$ and $25 \%$ Wood vinegar & $13 \%$ & $12 \%$ \\
\hline $\begin{array}{c}\text { Flash } \\
\text { pyrolysis }\end{array}$ & $\begin{array}{l}\text { High temperature }\left(>800^{\circ} \mathrm{C}\right) \text {, Fast heating rate } 1000^{\circ} \mathrm{C} / \mathrm{S} \text {, } \\
\text { gas vapor residence time }(<1 \mathrm{~S})\end{array}$ & $5 \%$ and $55 \%$ Wood vinegar & About $80 \%$ & About $10 \%$ \\
\hline
\end{tabular}

tended effort to enhance the procedure efficiency \& optimization of biochar generation by adjusting or controlling the operating conditions has not been widely because of past competition from bioenergy production. Carbonised organic matter can essentially have dissimilar physical and chemical properties based on the technology used for its production [90].

Some previous studies have compared the properties of more than a few types of biochars prepared through slow pyrolysis and found that pyrolysis temperature and biomass type are important factors in determining the most suitable application for biochars. Example, (Uchimiya et al.) discovered that pyrolysis methods can have an influence on the presence of surface practical groups on biochars and thus manage or control their heavy metal sequestration capability in soils [91]. Yao. et al. [92] reported biochars made from different biomass feedstock's show large differences in adsorbing phosphate from aqueous solutions. Moreover, biochar can be used as a low-cost adsorbent for wastewater treatment, especially with regards to processing or treating heavy metals in wastewater. Several studies have expounded effective removal of heavy metals from aqueous solutions by biochar and, in some situations, demonstrated the advantage of biochars to activated carbons [93].

Recent studies have also suggested that production/conversion methods can also play an important role in controlling biochar properties [94]. Example, biochars produced by hydrothermal carbonization, which is also called hydrochar, show unique characteristics and can be used for different applications, such as innovative materials and soil amelioration [94] [95].

On the other hand, Biomass pyrolysis or raw materials into biochar have been Carried out on olive pomace, oak bark, oak wood, pine wood, apple wood, corn stover, wheat straw, sugarcane bagasse, canola straw, compost, rice husk, dairy manure, bamboo, orange waste, peanut straw and switch grass [89] [96] [97] [98] [99]. Nearly every form of feedstock comprises plant residues; yard wastes, forestry wastes, animal manure, sewage sludge wastes and industrial wastes can be treated or in a pyrolyzer. Hence, not all biological litters are appropriate for making biochar that can be employed in agricultural scopes. This is due to certain creation conditions and biomasses generate biochar that cannot keep nu- 
trients efficiently, and are liable to microbial decompose [100]. Pyrolysis methods can be well-known via the residence time, pressure and size of adsorbent, pyrolytic temperature of the pyrolysis substance and heating rate and method [101] [102]. Table 3 shows the particular technique of characteristics and parameters of pyrolysis methods.

From Table 3, slow and middle pyrolysis can create greater yield of biochar, while fast methods can create additional liquid products and flash methods can create additional gas. Therefore, in order to obtain additional biochar, slow methods and middle methods pyrolysis is additional appropriate.

\subsection{How to Make Biochar Stove for Small Farms?}

Stove of biochar provide out 2 aims: it creates biochar and it lets to cook food on peak of it though it is creating the biochar. Flame created by a biochar stove is detergent and fewer contaminating than the flames that several kinds of stoves produce. It burns an extensive range of fuel than modest wood stoves do. It also creates biochar, which can utilize as a soil improvement and amendment. In addition a biochar stove is also small and easy to create. Figure 4 and Figure 5 show very simple a Top-Lit Up Draft (TLUD) biochar maker, whether you concerns: 1) Smoke reduction; 2) Biochar for your garden; 3) Fields; 4) Animal feed; 5) Stop stink and flies. This machine is good and design to be: 1) Inexpensive; 2) Easy to make (no especial tools, no especial training ); 3) Easy to use ; 4) Effective (no smoke, good biochar); 5) Portable; 6) Efficient (you don't spend a lot of time, collecting biomass, and then haven't reduce to handful of biochar, this thing you will give you about $30 \%$ efficiency [103].

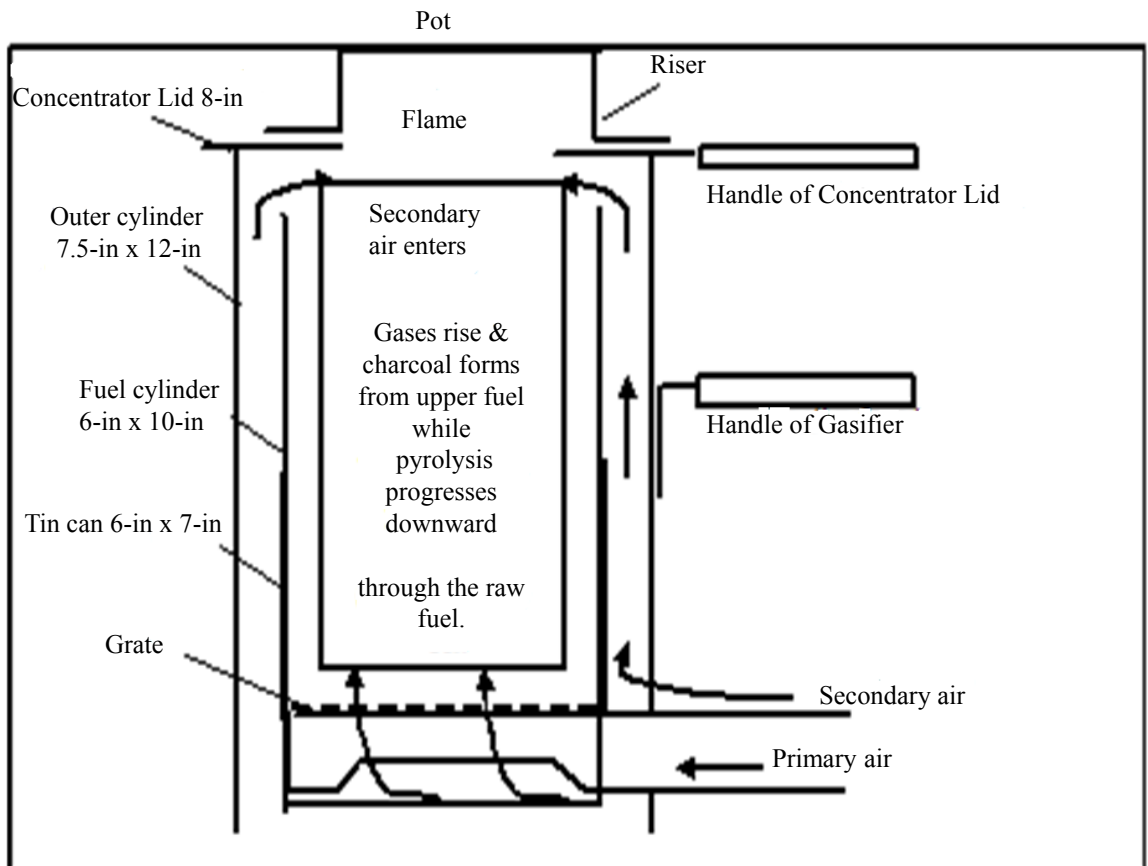

Figure 4. Show a vertical cross-section of the (TLUD) stove. TLUD allows for a clean burn [33]. 


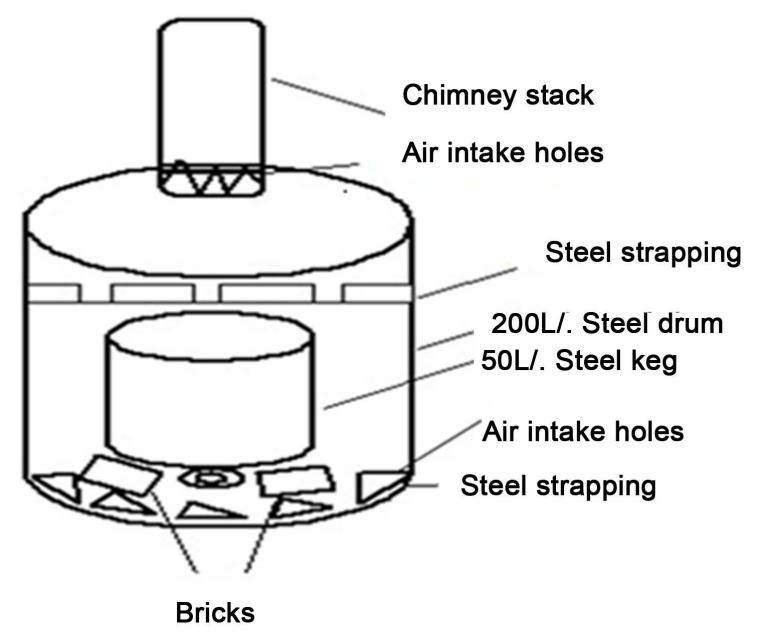

Figure 5. Show simple biochar stove of production biochar in small area.

\subsection{Materials and Tools Needed to Make Stove}

Some simple materials \& tools will be needed to make stove such as: 1) Large iron drums or steel keg (e.g. 55/gallons ); 2) sheet metal screws gauge rebar tie wire; 3) Hammer and a big; 4) sharp nail; 5) Tin snips; 6) File; 7) Opener; 8) Compass; 9) Pencil; 10) Sharpie marker; 11) Ruler; 12) Screwdriver; 13) Pliers; 14) Scribe line for cutting; 15) disk-cutter; 16) Scribe lines for the covers at 120 degree sections. The steps for make simple LTUD stove to made biochar in small farms and gardens as follow: 1) Remove the bottom cover; 2) Bare vessel; 3) Punch inside process air holes; 4) Punch outside process air holes; 5) Punch combustion air holes in base; 6) Make top holes; 7) Accessories; 8) Insert Vessel Into Paint Can; 9) Ready to Run. (For more information on this LTUD stove see [103].

\section{Frequently Asked Questions and Important Points}

\subsection{What Do Farmers Need to Be Acquainted with about Biochar?}

\section{What Is in Biochar?}

Biochar comprises stable matter, ashes, unstable matter \& moisture. Ashes comprise plant nutrients which can advantage plant growing in short period. The quantity or amount of ash in biochar can differ a lot. Biochars made from animal manures generally contain great sizes or proportions of ash, compared to biochars made from plant parts. Care must be taken when working with highash biochars. It is probable or possible to induce salt stress in the crop if too much is applied at once. Stable substance in biochar remains in soil over the long term and offers nutrient retention and other benefits to soil quality. Unstable substance decomposes in the months and years after biochar is added to soil.

\subsection{Studies Showing Improved Plant Growing with Applications of Biochar}

Several studies in temperate climates and tropical have established biochars capability to enhance plant growing, decrease discharge or leaching of nutrients, 
raise retention of water, and augment microbial activity. In Colombian Oxisol many studies are completed (type of soil also found widely in Hawai $i$ ), total belowground plant feed stocks improved via $189 \%$ when biochar was applied at an amount of 23.2 ton/ha [104]. Research point to that biological (N) nitrogen fixation and helpful mycorrhizal relations in widespread beans (Phaseolus vulgaris) are improved through biochar applications [105] [106]. In Brazil, occurrence of local plant kinds augmented with $63 \%$ in areas where biochar was applied [104]. Several studies have exposed that the properties of biochar most significant to plant growing can enhance over time after its combination into soil [59] [107] [108].

On the other hand, many studies indicating undesirable effects of biochar on plant growing, negative or neutral effects on yields were also gained. It is very important to know that biochar is not an actual fertilizer. Biochar constantly contains some ash and ash can provide nutrients to plants, for example (Ca) calcium, $(\mathrm{k})$ potassium, and $(\mathrm{Mg})$ magnesium. These nutrients are frequently limiting in very poor soils. Majority cases of reduced plant growing due to biochar utilization can be imputed to provisional levels of $\mathrm{pH},(\mathrm{MM})$ mobile matter and imbalances associated of nutrient with new biochar [32].

Biochar frequently can have a firstly high (alkaline) $\mathrm{pH}$, which is attractive when employed with acidic, degraded soils; however, if $\mathrm{pH}$ value becomes too alkaline, plants might undergo nutrient insufficiencies. "Volatile" indicates to resins, types of tar, and other short period materials that stay on the biochar surface forthwith after production and can stop plant growing [32] [33]. Highquality production practices can reduce the quantity of $\mathrm{MM}$ in the biochar. $\mathrm{Mi}$ crobial action can decompose and convert the carbon rich (MM) into nutrients for plants; however, in the procedure, the microorganisms need $(\mathrm{N})$ nitrogen \&additional soil elements, making them provisionally unavailable for uptake by plants. These transitional imbalances are afterwards corrected as mobile matter (MM) decomposes, unavailable nutrients are released and $\mathrm{pH}$ neutralizes. On the other hand, some study has demonstrated that biochar improvement to soil can outcome in a release of dissolved organic matter from soil as well as change the dissolved organic matter composition towards greater aromaticity. A rise in soil $\mathrm{pH}$ upon the addition of alkaline biochar, probable affected by alkaline ash found in biochar, clarified most of the observed release of dissolved organic matter [109].

\subsection{How Much Biochar Is Supposed to Be Applied?}

Most favorable application amount for biochar depends on the particular type of crop management and soil [10] [11]. And to note that not all biochar is the same, so it is imperative and significant point. The main physical and chemical properties of biochar are really affected by the kind of biomass being heated and the conditions of the pyrolysis method. For instance, biochar prepared from compost will have a greater nutrient substance or content than biochar prepared from wood. However, biochar prepared from wood might have a better grade of 
stability. Two several of biochars will look comparable but will behave completely in a different way. Several biochar resources, for example bones and manures, are mostly composed of ashes, and thus can provide considerable quantities of nutrients to crops. On the other hand, the carbon (C) content of great in organic ash biochars is low $(<10 \%)$, therefore longer period nutrient retention purposes will be less for a given quantity of substance. Variability in soils and biochar resources, employers of biochar should think about analyzing different amounts of biochar application on a few amounts before setting out to apply it on big areas [108]. At this time there is insufficient data available to allow the determination of perfect biochar application rates in dissimilar soils and cropping systems. Many researches indicate that minor application quantities yielded affirmative outcomes [110]. Also biochar can be applied incrementally and included with manure applications or fertilizer regimens applications. In field experiments published to date, rates of $2-22 \mathrm{t} / \mathrm{ac}(5-50 \mathrm{t} / \mathrm{ha}$ ) have given favourable or positive results. The maximum end of this range may not be feasible or practical in terms of biochar sourcing and incorporation to the soil and have considerably been used effectively or successfully [110].

\subsection{Biochar Application to Soils}

The aim of applying biochar to soil fundamentally falls into four broad categories [111]: a) Agricultural profitability; b) Management of pollution and eutrophication hazard to environment; c) Reconquest of degraded land; d) Sequestration of carbon from the atmosphere.

In nature happening biochar made from grassland and forest wastes, means that biochar can persist for thousands years with a few decompose. Therefore biochar has a long-lasting effect in soil, and that beneficial effects improve over time. Studies lab employing the modern methods evaluate that biochar has a mean residence time in soils to many thousand years [29] [107]. Biochar can be applied to soil by hand or using conventional machinery such as manure spreaders and lime, and should be thoroughly incorporated into the soil by tillage. In many cases, like perennial crops and other fruit orchards where plowing is not an option, biocharit can be: 1) used to the soil surface and, preferably, enclosed with other biological resources; 2) used mixed with compost or mulch; 3) used as a liquid slurry if delicately ground (on a big measure). However, biochar can rise microbial action and decrease nutrient damages through fertilizing or composting [112].

In the procedure, the biochar come to be "charged" with nutrients, wrapped with pH-balanced and microbes and content of MM (mobile matter) is decay into nutrients of plant. Irrespective of the application techniques, it is very significant to be careful when dealing with dryish biochar, which is very dusty and should not be prevalence in conditions of wind. This can be simply treated by moistening the biochar earlier application. In order to respiratory protection should be worn dust mask when handling the dry substance. 


\subsection{What Type of Biochar Is the Most Excellent and How to Obtain It?}

The majority significant procedures of the quality of biochar contain adsorption, mobile matter (MM), cation exchange capacity (CEC), (resins, tars, and other compounds) and kind of biological substance biomass employed. Over time, adsorption capacity of biochar reductions, while it's CEC rises [106], progresses porosity [48], and lowers bulk density thus creating root permeation easier. MM can prevent the porous and first adsorption but is extremely vulnerable to organic decompose, which can alleviate those effects. Biochar might also provide some quantity of nutrients [113] [114] and supply a liming influences to soil [115]. Structure physical of the biomass, mainly its size of pore, which very much controls water retention, surface area and organic employment of biochar created, is a basically protected into form through "modification thermal" While a larger fraction of microspore's might yield a greater surface area, and thus greater capability of nutrient retention, various soil microbes are too big to employ such minor spaces and advantage from some quantity of bigger sizes pore [106].

From where of rising plant growing, biochar with many sizes of pore might be most an excellent fitted to improve the physic-chemical and biological properties of soils. On the other hand, the procedure by which a biochar is created is a significant part influencing its quality. While several processes have constantly created small quality of biochar, other procedures, when done correctly, can yield great quality of biochar.

Biochar is a new product, and it can be very hard for farmers or peasants to find it in larger quantities, at an affordable price. Also, as of yet anyone can sell anything as biochar. This is why farmers or peasants and gardeners must be conscious that biochar can have a range of features or characteristics, and can potentially have positive, negative or unfavorable effects in their soil. It is suggested and recommended that you get as much information as possible from the provider, containing results of any plant growth examinations or tests they have done, and how these tests were conducted.

\section{Conclusion}

Biochar that has upgraded extensively is promoted to improve a range of soil properties and can be derived from a wide range of forest residue, sewage sludge, organic and agricultural wastes biomass feedstock, at different pyrolysis conditions and also can be made in simple or complex pyrolysis units and can be made in your backyard or on your farm. The properties of biochar specified by chemical and physical processes reveal the infrastructure of biochar. Biochar defined by its useful application to soil, is expected to enhance an advantage from enduring chemical and physical properties. Studies of charcoal tend to suggest stability in the order of many years in the normal environment, and various analytical methods inform quantification and an understanding of turn over processes. For large surface area and porosity of biochar, they can raise the ca- 
pacity of water holding of soil and the absorption of nutrients with a view to decrease loss and an augment soil structure, so biochar might progress fertility of soil and raise crop yields in future if it is applied to soil with a suitable application rates.

\section{Acknowledgements}

Firstly, I render my prayers and thank the most Gracious and Merciful "Allah" who helped me to carry out this paper successfully. This paper was conducted and supported by the School of Environmental and Municipal Engineering, Lanzhou Jiaotong University, Lanzhou 730070, China. In great indebtedness and gratitude I would like to express my deepest appreciation to my supervisor Prof. Baowei Zhao, for his generous assistance, keen interest and his useful guidance.

\section{References}

[1] FAO (2010) "Climate Smart" Agriculture; Policies, Practices and Financing for Food Security, Adaptation and Mitigation. Rome.

[2] Foresight (2011) The Future of Food and Farming; Challenges and Choices for Global Sustainability; Final Project Report. The Government Office for Science, London.

[3] Beddington, J.R., Clark, M.E., Fernández Bremauntz, A., Asaduzzaman, M., Guillou, M.D., Jahn, M.M., Lin, E., Mamo, T., Negra, C., Nobre, C.A., Scholes, R.J., Sharma, R., Van Bo, N. and Wakhungu, J. (2012) The Role for Scientists in Tackling Food Insecurity and Climate Change. Agriculture \& Food Security, 1, 10. https://doi.org/10.1186/2048-7010-1-10

[4] Beddington, J., Clark, M., Asaduzzaman, M., Fernández, A., Guillou, M., Jahn, M., Erda, L., Mamo, T., Van Bo, N., Nobre, C.A., Scholes, R., Wakhungu, J. and Sharmam, R. (2012) Achieving Food Security in the Face of Climate Change; Final Report from the Commission on Sustainable Agriculture and Climate Change. CGIAR Research Program on Climate Change. Copenhagen, Denmark, Agriculture and Food Security (CCAFS). www.ccafs.cgiar.org/commission

[5] HLPE (2012) Food Security and Climate Change. A Report by the (HLPE) on Food Security and Nutrition of the Committee on World Food Security, Rome.

[6] (1991) Agriculture, Livestock, Fisheries and Forestry in Sudan. Embassy of the Republic of Sudan, Washington DC, Library of Congress.

[7] (2008) Sudan Agriculture. Nations Encyclopedia. Archived from the original on $7 / 10 / 2008$.

[8] Schmidt-Rohr, K. and Spiess, H.W. (1994) Multidimensional Solid-State NMR and Polymers. Academic Press, San Diego.

[9] Duer, M.J. (2004) Introduction to Solid-State NMR Spectroscopy. Blackwell, Malden, MA.

[10] Taylor, P. (2010) The Biochar Revolution; Transforming Agriculture and Environment. Global Publishing G. http://biochar-books.com/TBRDetails

[11] Bates, A. (2010) The Biochar Solution: Carbon Farming and Climate Change, New Society. http://www.newsociety.com/bookid/4078

[12] Bruges, J. (2010) The Biochar Debate: Charcoal's Potential to Reverse Climate Change and Build Soil Fertility. The Schumacher Briefing, Chelsea Green Publisher. https://www.amazon.com/ 
[13] Lehmann, J.S. (2009) Biochar for Environmental Management. Earthscan, Oxford, UK.

[14] Kajitani, S., Tay, H.-L., Zhang, S. and Li, C.-Z. (2013) Mechanisms and Kinetic Modelling of Steam Gasification of Brown Coal in the Presence of Volatile-Char Interactions. Fuel, 103, 7-13. https://doi.org/10.1016/j.fuel.2011.09.059

[15] Zhao, B. and Nartey, O.D. (2014) Characterization and Evaluation of Biochars Derived from Agricultural Waste Biomasses from Gansu, China. Proceedings of the World Congress on Advances in Civil, Environmental, and Materials Research, Busan, Republic of Korea.

[16] Chen, W.F., Zhang, W.M., Meng, J. and Xu, Z.J. (2011) Biochar Application Technology Research. Chinese Engineering Science, 13, 83-89.

[17] Kuppusamy, S., Thavamani, P., Megharaj, M., Venkateswarlu, K. and Naidu, R. (2016) Agronomic and Remedial Benefits and Risks of Applying Biochar to Soil: Current Knowledge and Future Research Directions. Environment International, 87, 1-12. https://doi.org/10.1016/j.envint.2015.10.018

[18] Ma, J., et al. (2013) Odor in Commercial Scale Compost; Literature Review and Critical Analysis. Washington State Department of Ecology, 17 October, Olympia, Washington DC, 74.

[19] Currie, C. and Briones, A. (2012) Aerobic and Anaerobic Composting with Biochar. ASM 2012, The 112 th General Meeting of the American Society for Microbiology, San Francisco, CA, USA.

[20] Carpenter, A. and Tilth, N. (2013) High Carbon Wood Fly Ash as a Biochar Soil Amendment. Proceedings of the North American Biochar Symposium, USBI 12.

[21] Rodrigues, C.C., de Moraes Jr., D., da Nóbrega, S.W. and Barboza, M.G. (2006) Ammonia Adsorption in a Fixed Bed of Activated Carbon. Bioresource Technology, 98, 886-891. https://doi.org/10.1016/j.biortech.2006.03.024

[22] Iyobe, T., Asada, T., Kawata, K. and Oikawa, K. (2004) Comparison of Removal Efficiencies for Ammonia and Amine Gases between Woody Charcoal and Activated Carbon. Journal of Health Science, 50, 148-153.

[23] Rosenfeld, P.E. and Henry, C.L. (1662-1668) Wood Ash Control of Odor from Biosolids Application. Journal of Environmental Quality, 29.

[24] Sonoki, T., Furukawa, T., Jindo, K., Suto, K., Aoyama, M. and Sánchez-Monedero, M.Á. (2012) Influence of Biochar Addition on the Methane Metabolism during Thermophile Phase of Composting. Journal of Basic Microbiology, 53, 617-621. https://doi.org/10.1002/jobm.201200096

[25] Borchard, N., Kautz, T., Prost, K., Moeller, A. and Siemens, J. (2012) Sorption of Copper (II) and Sulphate to Different Biochars Before and after Composting with Farmyard Manure. European Journal of Soil Science, 63, 399-409. https://doi.org/10.1111/j.1365-2389.2012.01446.x

[26] Houben, D., Evrard, L. and Sonnet, P. (2013) Mobility, Bioavailability and pH-Dependent Leaching of Cadmium, Zinc and Lead in a Contaminated Soil Amended with Biochar. Chemosphere, 92, 1450-1457. https://doi.org/10.1016/j.chemosphere.2013.03.055

[27] Uchimiya, M., Lima, I.M., Klasson, K.T., Chang, S., Warlette, L.H. and Rodrigers, E.J. (2010) Immobilization of Heavy Metal Ions ( $\mathrm{Cd}^{\mathrm{II}}, \mathrm{Cu}^{\mathrm{II}}, \mathrm{Ni}^{\mathrm{II}}$, and $\left.\mathrm{Pb}^{\mathrm{II}}\right)$ by Broiler Litter Derived Biochars in Water and Soil. Journal of Agricultural and Food Chemistry, 58, 5538-5544. https://doi.org/10.1021/jf9044217

[28] Rees, F., Simonnot, M.O. and Morel, J.L. (2014) Short-Term Effects of Biochar on Soil Heavy Metal Mobility Are Controlled by Intra-Particle Diffusion and Soil pH 
Increase. European Journal of Soil Science, 65, 149-161. https://doi.org/10.1111/ejss.12107

[29] Liang, B.Q., Lehmann, J., Solomon, D., Sohi, S., Thies, J.E., Skjemstad, J.O., Luizão, F.J., Engelhard, M.H., Neves, E.G. and Wirick, S. (2008) Stability of Biomass-Derived Black Carbon in Soils. Geochimica et Cosmochimica Acta, 72, 6096-6078. https://doi.org/10.1016/i.gca.2008.09.028

[30] Woolf, D., Amonette, J.E., Street-Perrott, F.A., Lehmann, J. and Joseph, S. (2010) Sustainable Biochar to Mitigate Global Climate Change. Nature Communications, 1, Article No. 56. www.nature.com/ncomms/journal/v1/n5/full/ncomms1053.html

[31] Lehmann, (2007) Biochar is created by heating organic material under conditions of limited or no oxygen.

[32] McClellan, T., Uehara, G., Deenik, J. and Antal, M. (2007) Effects of Flashed Carbonized Macadamia Nutshell Charcoal on Plant Growth and Soil Chemical Properties. 6 November 2007, SSA, ASA, CSSA, International Annual Meetings, Louisiana, New Orleans. http://ac-s.confex.com/crops/2007am/techprogram/P35834.HTM

[33] McLaughlin, H., Anderson, P.S., Shields, F.E. and Reed, T.B. (2009) All Biochars Are Not Created Equal, and How to Tell Them Apart. Proceedings of the North American Biochar Conference, Boulder, Colorado, 8/2009.

www.biochar-international.org/sites/default/files/All-Biochars--Version2--Oct2009. pdf

[34] Angin, D. (2013) Effect of Pyrolysis Temperature and Heating Rate on Biochar Obtained from Pyrolysis of Safflower Seed Press Cake. Bioresource Technology, 128, 593-597. https://doi.org/10.1016/j.biortech.2012.10.150

[35] Shivaram, P., Leong, Y.K., Yang, H. and Zhang, K.D. (2013) Flow and Yield Stress Behaviour of Ultrafine Mallee Biochar Slurry Fuels: The Effect of Particle Size Distribution and Additives. Fuel, 104, 326-332.

[36] Kasozi, G.N., Zimmerman, A.R., Nkedi-Kizza, P. and Gao, B. (2010) Catechol and Humic Acid Sorption onto a Range of Laboratory-Produced Black Carbons (Biochars). Environmental Science \& Technology, 44, 6189-6195. https://doi.org/10.1021/es1014423

[37] Beeseley, L. and Marmiroli, M. (2011) The Immobilisation and Retention of Soluble Arsenic, Cadmium and Zinc by Biochar. Environmental Pollution, 159, 474-480. https://doi.org/10.1016/j.envpol.2010.10.016

[38] Xu, T., Lou, L., Luo, L., Cao, R., Duan, D. and Chen, Y. (2012) Effect of Bamboo Biochar on Pentachlorophenol Leachability and Bioavailability in Agricultural Soil. Science of the Total Environment, 414, 727-731. https://doi.org/10.1016/j.scitotenv.2011.11.005

[39] Cao, X. and Harris, W. (2010) Properties of Dairy-Manure-Derived Biochar Pertinent to Its Potential Use in Remediation. Bioresource Technology, 101, 5222-5228. https://doi.org/10.1016/j.biortech.2010.02.052

[40] Song, W. and Guo, M. (2012) Quality Variations of Poultry Litter Biochar Generated at Different Pyrolysis Temperatures. Journal of Analytical and Applied Pyrolysis, 94, 138-145. https://doi.org/10.1016/j.jaap.2011.11.018

[41] Tsai, W., Liu, S. and Hsieh, C. (2012) Preparation and Fuel Properties of Biochars from the Pyrolysis of Exhausted Coffee Residue. Journal of Analytical and Applied Pyrolysis, 93, 63-67. https://doi.org/10.1016/j.jaap.2011.09.010

[42] de Wild, P.J., Huijgen, W.J.J. and Heeres, H.J. (2012) Pyrolysis of Wheat Straw-Derived Organosolv Lignin. Journal of Analytical and Applied Pyrolysis, 93, 95-103. 
https://doi.org/10.1016/j.jaap.2011.10.002

[43] Liu, Z. and Zhang, F. (2009) Removal of Lead from Water Using Biochars Prepared from Hydrothermal Liquefaction of Biomass. Journal of Hazardous Materials, 167, 933-939. https://doi.org/10.1016/j.jhazmat.2009.01.085

[44] Zhao, X.W., Ouyang, W., Hao, F., et al. (2013) Properties Comparison of Biochars from Corn Straw with Different Pretreatment and Sorption Behavior of Atrazine. Bioresource Technology, 147, 338-344. https://doi.org/10.1016/j.biortech.2013.08.042

[45] Wang, T., Cheng, J., Liu, J., Jiang, W., Zhang, C. and Yu, X. (2012) Effect of Biochar Amendment on the Bioavailability of Pesticide Chlorantraniliprole in Soil to Earthworm. Ecotoxicology and Environmental Safety, 83, 96-101. https://doi.org/10.1016/j.ecoenv.2012.06.012

[46] Lou, L., Luo, L., Yang, Q., et al. (2012) Release of Pentachlorophenol from Black Carbon-Inclusive Sediments under Different Environmental Conditions. Chemosphere, 88, 598-604. https://doi.org/10.1016/j.chemosphere.2012.03.039

[47] Lu, H., Zhang, W., Yang, Y., Huang, X., Wang, S. and Qiu, R. (2012) Relative Distribution of $\mathrm{Pb}^{2+}$ Sorption Mechanisms by Sludge Derived Biochar. Water Research, 46, 854-862. https://doi.org/10.1016/j.watres.2011.11.058

[48] Funke, A. and Ziegler, F. (2010) Hydrothermal Carbonization of Biomass: A Summary and Discussion of Chemical Mechanisms for Process Engineering. Biofuels, Bioproducts and Biorefining, 4, 160-177. https://doi.org/10.1002/bbb.198

[49] Bird, M.I., Ascough, P.L., Young, I.M., Wood, C.V. and Scott, A.C. (2008) X-Ray Microtomographic Imaging of Charcoal. Journal of Archaeological Science, 35, 2698-2706. https://doi.org/10.1016/j.jas.2008.04.018

[50] Abdullah, H. and Wu, H. (2009) Biochar as a Fuel: 1. Properties and Grind Ability of Biochars Produced from the Pyrolysis of Mallee Wood under Slow-Heating Conditions. Energy and Fuels, 23, 4174-4181. https://doi.org/10.1021/ef900494t

[51] Agblevor, F.A., Kim, S.S., Beis, S., Tarrant, R. and Mante, N.O. (2010) Biocrude Oils from the Fast Pyrolysis of Poultry Litter and Hardwood. Waste Management, 30, 298-307. https://doi.org/10.1016/j.wasman.2009.09.042

[52] Gaskin, J.W., Steiner, C., Harris, K., Das, K.C. and Bibens, B. (2008) Effect of Low-Temperature Pyrolysis Conditions on Biochar for Agricultural Use. Transactions of the ASABE, 51, 2061-2069. https://doi.org/10.13031/2013.25409

[53] Lua, A.C., Yang, T. and Guo, J. (2004) Effects of Pyrolysis Conditions on the Properties of Activated Carbons Prepared from Pistachio-Nut Shells. Journal of Analytical and Applied Pyrolysis, 72, 279-287. https://doi.org/10.1016/j.jaap.2004.08.001

[54] Brown, R.A., Kercher, A.K., Nguyen, T.H., Nagle, D.C. and Ball, W.P. (2006) Production and Characterization of Synthetic Wood Chars for Use as Surrogates for Natural Sorbents. Organic Geochemistry, 37, 321-333. https://doi.org/10.1016/j.orggeochem.2005.10.008

[55] Antal Jr., M.J., Allen, S.G., Dai, X., Shimizu, B., Tam, M.S. and Grønli, M. (2000) Attainment of the Theoretical Yield of Carbon from Biomass. Industrial and Engineering Chemistry Research, 39, 4024-4031. https://doi.org/10.1021/ie000511u

[56] Atkinson, C.J., Fitzgerald, J.D. and Hipps, N.A. (2010) Potential Mechanisms for Achieving Agricultural Benefits from Biochar Application to Temperate Soils: A Review. Plant and Soil, 337, 1-18. https://doi.org/10.1007/s11104-010-0464-5

[57] Joseph, S.D., Camps-Arbestain, M., Lin, Y., Munroe, P., Chia, C.H., Hook, J., van Zwieten, L., Kimber, S., Cowie, A., Singh, B.P., Lehmann, J., Foidl, N., Smernik, R.J. and Amonette, J.E. (2010) An Investigation into the Reactions of Biochar in Soil. 
Australian Journal of Soil Research, 48, 501-515. https://doi.org/10.1071/SR10009

[58] Sharma, R.K., Wooten, J.B., Baliga, V.L., Lin, X., Chan, W.G. and Hajaligol, M.R. (2004) Characterization of Chars from Pyrolysis of Lignin. Fuel, 83, 1469-1482. https://doi.org/10.1016/j.fuel.2003.11.015

[59] Cheng, C.H., Lehmann, J., Thies, J.E., Burton, S.D. and Engelhard, M.H. (2006) Oxidation of Black Carbon by Biotic and Abiotic Processes. Organic Geochemistry, 37, 1477-1488. https://doi.org/10.1016/j.orggeochem.2006.06.022

[60] Brewer, C.E., Schmidt-Rohr, K., Satrio, J.A. and Brown, R.C. (2009) Characterization of Biochar from Fast Pyrolysis and Gasification Systems. Environmental Progress and Sustainable Energy, 28, 386-396. https://doi.org/10.1002/ep.10378

[61] Cohen-Ofri, H., Popovitz-Biro, R. and Weiner, S. (2007) Structural Characterization of Modern and Fossilized Charcoal Produced in Natural Fires as Determined by Using Electron Energy Loss Spectroscopy. Chemistry-A European Journal, 13, 2306-2310. https://doi.org/10.1002/chem.200600920

[62] Boehm, H. P. (1994) Some Aspects of the Surface Chemistry of Carbon Blacks and Other Carbons. Carbon, 32, 759-769. https://doi.org/10.1016/0008-6223(94)90031-0

[63] Özçimen, D. and Ersoy-Meriçboyu, A. (2008) A Study on the Carbonization of Grapeseed and Chestnut Shell. Fuel Processing Technology, 89, 1041-1046. https://doi.org/10.1016/j.fuproc.2008.04.006

[64] Ayllón, M., Aznar, M., Sánchez, J.L., Gea, G. and Arauzo, J. (2006) Influence of Temperature and Heating Rate on the Fixed Bed Pyrolysis of Meat and Bone Meal. Chemical Engineering Journal, 121, 85-96. https://doi.org/10.1016/j.cej.2006.04.013

[65] Yilmaz, O., Cem Kantarli, I., Yuksel, M., Saglam, M. and Yanik, J. (2007) Conversion of Leather Wastes to Useful Products. Resources, Conservation and Recycling, 49, 436-448. https://doi.org/10.1016/j.resconrec.2006.05.006

[66] Gerçel, H.F. (2002) The Production and Evaluation of Bio-Oils from the Pyrolysis of Sunflower-Oil Cake. Biomass and Bioenergy, 23, 307-314. https://doi.org/10.1016/S0961-9534(02)00053-3

[67] Onay, O. and Koçkar, O.M. (2003) Slow, Fast and Flash Pyrolysis of Rapeseed. Renewable Energy, 28, 2417-2433. https://doi.org/10.1016/S0960-1481(03)00137-X

[68] Özbay, N., Pütün, A.E. and Pütün, E. (2001) Structural Analysis of Bio-Oils from Pyrolysis and Steam Pyrolysis of Cottonseed Cake. Journal of Analytical and Applied Pyrolysis, 60, 89-101. https://doi.org/10.1016/S0165-2370(00)00161-3

[69] Şensöz, S. (2003) Slow Pyrolysis of Wood Barks from Pinus brutia Ten. and Product Compositions. Bioresource Technology, 89, 307-311. https://doi.org/10.1016/S0960-8524(03)00059-2

[70] Katyal, S., Thambimuthu, K. and Valix, M. (2003) Carbonisation of Bagasse in a Fixed Bed Reactor: Influence of Process Variables on Char Yield and Characteristics. Renewable Energy, 28, 713-725. https://doi.org/10.1016/S0960-1481(02)00112-X

[71] Özyurtkan, M.H., Özçimen, D. and Meriçboyu, A.E. (2008) Investigation of the Carbonization Behavior of Hybrid Poplar. Fuel Processing Technology, 89, 858-863. https://doi.org/10.1016/j.fuproc.2008.02.005

[72] Yip, K., Xu, M., Li, C.-Z., Jiang, S.P. and Wu, H. (2011) Biochar as a Fuel: 3. Mechanistic Understanding on Biochar Thermal Annealing at Mild Temperatures and Its Effect on Bioc har Reactivity. Energy and Fuels, 25, 406-414. https://doi.org/10.1021/ef101472f

[73] Joseph, S., Lehmann, J., Peacock, C. and Munroe, P. (2009) Developing a Biochar Classification and Test Methods. In: Lehmann, J. and Joseph, S., Eds., Biochar for 
Environmental Management, Earthscan, UK, 107-126.

[74] Karaosmanoğlu, F., Işigigür-Ergüdenler, A. and Sever, A. (2000) Biochar from the Straw-Stalk of Rapeseed Plant. Energy and Fuels, 14, 336-339. https://doi.org/10.1021/ef9901138

[75] Sánchez, M.E., Lindao, E., Margaleff, D., Martínez, O. and Morán, A. (2009) Pyrolysis of Agricultural Residues from Rape and Sunflowers: Production and Characterization of Bio-Fuels and Biochar Soil Management. Journal of Analytical and Applied Pyrolysis, 85, 142-144. https://doi.org/10.1016/j.jaap.2008.11.001

[76] Özçimen, D. and Karaosmanoğlu, F. (2004) Production and Characterization of Bio-Oil and Biochar from Rape Seed Cake. Renewable Energy, 29, 779-787. https://doi.org/10.1016/j.renene.2003.09.006

[77] Özçimen, D. and Ersoy-Meriçboyu, A. (2010) Characterization of Biochar and Bio-Oil Samples Obtained from Carbonization of Various Biomass Materials. Renewable Energy, 35, 1319-1324. https://doi.org/10.1016/j.renene.2009.11.042

[78] Sánchez, M.E., Lindao, E., Margaleff, D., Martínez, O. and Morán, A. (2009) BioFuels and Bio-Char Production from Pyrolysis of Sewage Sludge. Journal of Residuals Science and Technology, 6, 35-42.

[79] Hossain, M.K., Strezov, V., Chan, K.Y., Ziolkowski, A. and Nelson, P.F. (2011) Influence of Pyrolysis Temperature on Production and Nutrient Properties of Wastewater Sludge Biochar. Journal of Environmental Management, 92, 223-228. https://doi.org/10.1016/j.jenvman.2010.09.008

[80] Purevsuren, B., Avid, B., Tesche, B. and Davaajav, Y. (2003) A Biochar from Casein and Its Properties. Journal of Materials Science, 38, 2347-2351.

https://doi.org/10.1023/A:1023980429410

[81] Grierson, S., Strezov, V., Ellem, G., Mcgregor, R. and Herbertson, J. (2009) Thermal Characterisation of Microalgae under Slow Pyrolysis Conditions. Journal of Analytical and Applied Pyrolysis, 85, 118-123. https://doi.org/10.1016/j.jaap.2008.10.003

[82] Mahinpey, N., Murugan, P., Mani, T. and Raina, R. (2009) Analysis of Bio-Oil, Biogas, and Biochar from Pressurized Pyrolysis of Wheat Straw Using a Tubular Reactor. Energy and Fuels, 23, 2736-2742. https://doi.org/10.1021/ef8010959

[83] Worasuwannarak, N., Potisri, P. and Tanthapanichakoon, W. (2006) Upgrading of Biomass by Carbonization in Hot Compressed Water. Songklanakarin Journal of Science and Technology, 28, 1049-1057.

[84] Steinbeiss, S., Antonietti, M. and Gleixner, G. (2009) Effect of Biochar Amendment on Soil Carbon Balance and Soil Microbial Activity. Soil Biology and Biochemistry, 41, 1301-1310. https://doi.org/10.1016/j.soilbio.2009.03.016

[85] Fuertes, A.B., Arbestain, M.C., Sevilla, M., Maclá-Agulló, J.A., Fiol, S., López, R., Smernik, R.J., Aitkenhead, W.P., Arce, F. and Maclas, F. (2010) Chemical and Structural Properties of Carbonaceous Products Obtained by Pyrolysis and Hydrothermal Carbonisation of Corn Stover. Australian Journal of Soil Research, 48, 618-626.

[86] Lei, H., Ren, S. and Julson, J. (2009) The Effects of Reaction Temperature and Time and Particle Size of Corn Stover on Microwave Pyrolysis. Energy and Fuels, 23, 3254-3261. https://doi.org/10.1021/ef9000264

[87] Sparkes, J. and Stoutjesdijk, P. (2011) Biochar: Implications for Agricultural Productivity. Australian Bureau of Agricultural and Resource Economics and Sciences Technical Report 11, 6 December 2011. Department of Agriculture, Fisheries and Forestry, Government of Australia, Canberra. 
[88] Singh, R., Babu, J.N., Kumar, R., Srivastava, P., Singh, P. and Raghubanshi, A.S. (2015) Multifaceted Application of Crop Residue Biochar as a Tool for Sustainable Agriculture: An Ecological Perspective. Ecological Engineering, 77, 324-347. https://doi.org/10.1016/j.ecoleng.2015.01.011

[89] Mohan, D., Sarswat, A., Ok, Y.S. and Pittman Jr., C.U. (2014) Organic and Inorganic Contaminants Removal from Water with Biochar, a Renewable, Low Cost and Sustainable Adsorbent-A Critical Review. Bioresource Technology, 160, 191- 202. https://doi.org/10.1016/j.biortech.2014.01.120

[90] Zhang, M., Gao, B., Varnoosfaderani, S., Hebard, A., Yao, Y. and Inyang, M. (2013) Preparation and Characterization of a Novel Magnetic Biochar for Arsenic Removal. Bioresource Technology, 130, 457-462. https://doi.org/10.1016/j.biortech.2012.11.132

[91] Uchimiya, M., Wartelle, L.H., Klasson, K.T., Fortier, C.A. and Lima, I.M. (2011) Influence of Pyrolysis Temperature on Biochar Property and Function as a Heavy Metal Sorbent in Soil. Journal of Agricultural and Food Chemistry, 59, 2501-2510. https://doi.org/10.1021/jf104206c

[92] Yao, Y., Gao, B., Inyang, M., Zimmerman, A.R., Cao, X., Pullammanappallil, P. and Yang, L. (2011) Biochar Derived from Anaerobically Digested Sugar Beet Tailings: Characterization and Phosphate Removal Potential. Bioresource Technology, 102, 6273-6278. https://doi.org/10.1016/j.biortech.2011.03.006

[93] Komkiene, J. and Baltrenaite, E. (2016) Biochar as Adsorbent for Removal of Heavy Metal Ions [Cadmium(II), Copper(II), Lead(II), Zinc(II)] from Aqueous Phase. International Journal of Environmental Science and Technology, 13, 471-482. https://doi.org/10.1007/s13762-015-0873-3

[94] Libra, J.A., Ro, K.S., Kammann, C., Funke, A., Berge, N.D., Neubauer, Y., Titirici, M.-M., Fühner, C., Bens, O., Kern, J. and Emmerich, K.-H. (2011) Hydrothermal Carbonization of Biomass Residuals: A Comparative Review of the Chemistry, Processes and Applications of Wet and Dry Pyrolysis. Biofuels, 2, 89-124.

[95] Xue, Y., Gao, B., Yao, Y., Inyang, M., Zhang, M., Zimmerman, A.R. and Ro, K.S. (2012) Hydrogen Peroxide Modification Enhances the Ability of Biochar (Hydrochar) Produced from Hydrothermal Carbonization of Peanut Hull to Remove Aqueous Heavy Metals: Batch and Column Tests. Chemical Engineering Journal, 200, 673-680.

[96] Barrow, C.J. (2012) Biochar: Potential for Countering Land Degradation and for Improving Agriculture. Applied Geography, 34, 21-28.

https://doi.org/10.1016/j.apgeog.2011.09.008

[97] Ducey, T.F., Ippolito, J.A., Cantrell, K.B., Novak, J.M. and Lentz, R.D. (2013) Addition of Activated Switch Grass Biochar to an Aridic Subsoil Increases Microbial Nitrogen Cycling Gene Abundances. Applied Soil Ecology, 65, 65-72. https://doi.org/10.1016/j.apsoil.2013.01.006

[98] Cao, X., Zhong, L., Peng, X., Sun, S., Li, S., Liu, S. and Sun, R. (2014) Comparative Study of the Pyrolysis of Lignocellulose and Its Major Components: Characterization and Overall Distribution of Their Biochars and Volatiles. Bioresource Technology, 155, 21-27. https://doi.org/10.1016/j.biortech.2013.12.006

[99] Junna, S., Bingchen, W., Gang, X. and Hongbo, S. (2014) Effects of Wheat Straw Biochar on Carbon Mineralization and Guidance for Large-Scale Soil Quality Improvement in the Coastal Wetland. Ecological Engineering, 62, 43-47. https://doi.org/10.1016/j.ecoleng.2013.10.014

[100] Ogbonnaya, U. and Semple, K.T. (2013) Impact of Biochar on Organic Contaminants in Soil: A Tool for Mitigating Risk? Agronomy, 3, 349-375. 
https://doi.org/10.3390/agronomy3020349

[101] Lehmann J., Gaunt J. and Rondon M. (2006) Bio-Char Sequestration in Terrestrial Ecosystems-A Review. Mitigation and Adaptation Strategies for Global Change, 11, 395-419. https://doi.org/10.1007/s11027-005-9006-5

[102] Duku, M.H., Gu, S. and Hagan, E.B. (2011) Biochar Production Potential in Ghana-A Review. Renewable and Sustainable Energy Reviews, 15, 3539-3551. https://doi.org/10.1016/j.rser.2011.05.010

[103] Environmental Program (2016). http://www.warmheartworldwide.org/

[104] Major, J., Steiner, C., Ditommaso, A., Falcao, N.P.S. and Lehmann, J. (2005) Weed Composition and Cover after Three Years of Soil Fertility Management in the Central Brazilian Amazon: Compost, Fertilizer, Manure and Charcoal Applications. Weed Biology and Management, 5, 69-76. https://doi.org/10.1111/j.1445-6664.2005.00159.x

[105] Rondon, M.A., Lehmann, J., Ramirez, J. and Hurtado, M. (2007) Biological Nitrogen Fixation by Common Beans (Phaseolus vulgaris L.) Increases with Bio-Char Additions. Biology and Fertility of Soils, 43, 699-708.

https://doi.org/10.1007/s00374-006-0152-z

[106] Warnock, D.D., Lehmann, J., Kuyper, T.W. and Rillig, M.C. (2007) Mycorrhizal Responses to Biochar in Soil-Concepts and Mechanisms. Plant and Soil, 300, 9-20. https://doi.org/10.1007/s11104-007-9391-5

[107] Cheng, C.-H., Lehmann, J. and Engelhard, M. (2008) Natural Oxidation of Black Carbon in Soils: Changes in Molecular Form and Surface Charge along a Climosequence. Geochimica et Cosmochimica Acta, 72, 1598-1610. https://doi.org/10.1016/j.gca.2008.01.010

[108] Major, J., Rondon, M., Molina, D., Riha, S.J. and Lehmann, J. (2010) Maize Yield and Nutrition after 4 Years of Doing Biochar Application to a Colombian Savanna Oxisol. Plant and Soil, 333, 117-128. https://doi.org/10.1007/s11104-010-0327-0

[109] Smebye, A., Alling, V., Vogt, R.D., Gadmar, T.C., Mulder, J., Cornelissen, G. and Hale, S.E. (2016) Biochar Amendment to Soil Changes Dissolved Organic Matter Content and Composition. Chemosphere, 142, 100-105. https://doi.org/10.1016/j.chemosphere.2015.04.087

[110] Glaser B., Lehmann, J. and Zech, W. (2002) Ameliorating Physical and Chemical Properties of Highly Weathered Soils in the Tropics with Charcoal-A Review. Biology and Fertility of Soils, 35, 219-230. https://doi.org/10.1007/s00374-002-0466-4

[111] Dias, B.O., Silva, C.A., Higashikawa, F.S., Roig, A. and Sanchez-Monedero, M.A. (2010) Use of Biochar as Bulking Agent for the Composting of Poultry Manure: Effect on Organic Matter Degradation and Humification. Bioresource Technology, 101, 1239-1246. https://doi.org/10.1016/j.biortech.2009.09.024

[112] Chan, K. and Xu, Z. (2009) Biochar: Nutrient Properties and Their Enhancement. In: Lehmann, J. and Joseph, S., Eds., Biochar for Environmental Management: Science and Technology, Earthscan, London, UK, 67-84.

[113] Gaskin, J.W., Speir, R.A., Harris, K., Das, K.C., Lee, R.D., Morris, L.A. and Fisher, D.S. (2010) Effect of Peanut Hull and Pine Chip Biochar on Soil Nutrients, Corn Nutrient Status, and Yield. Agronomy Journal, 102, 623-633. https://doi.org/10.2134/agronj2009.0083

[114] (2016) Biochar for Environmental Management: Science and Technology. http://www.biochar-international.org/projects/book

[115] Van Zwieten, L., Kimber, S., Morris, S., Chan, K.Y., Downie, A., Rust, J., Joseph, S. and Cowie, A. (2010) Effects of Biochar from Slow Pyrolysis of Papermill Waste on 
Agronomic Performance and Soil Fertility. Plant and Soil, 327, 235-246. https://doi.org/10.1007/s11104-009-0050-X

[116] Hossain, M.K., Strezov, V., Chan, Y.K. and Nelson, P.F. (2010) Agronomic Properties of Wastewater Sludge Biochar and Bioavailability of Metals in Pro- duction of Cherry Tomato (Lycopersicon esculentum). Chemosphere, 78, 1167-1171. https://doi.org/10.1016/j.chemosphere.2010.01.009

[117] Zhang, A., Ciu, L., Pan, G., Li, L., Hussain, Q., Zhang, X., Zheng, J. and Crowley, D. (2010) Effect of Biochar Amendment on Yield and Methane and Nitrous Oxide Emissions from Rice Paddy from Tai Lake plain, China. Agriculture, Ecosystem \& Environment, 139, 469-475. https://doi.org/10.1016/j.agee.2010.09.003

[118] Peng, X., Ye, L.L., Wang, C.H., Zhou, H. and Sun, B. (2011) Temperature- and Duration-Dependent Rice Straw-Derived Biochar: Characteristics and Effects on Soil Properties of an Ultisol in Southern China. Soil and Tillage Research, 112, 159-166. https://doi.org/10.1016/j.still.2011.01.002

[119] Rodríguez, L., Salazar, P. and Preston, T.R. (2009) Effect of Biochar and Biodigester Effluent on Growth of Maize in Acid Soils. Livestock Research for Rural Development, 21, Article No. 110. http://www.lrrd.org/lrrd21/7/rodr21110.htm

[120] Kimetu, J.M., Lehmann, J., Ngoze, S.O., Mugendi, D.N., Kinyangi, J.M., Riha, S., Verchot, L., Recha, J.W. and Pell, A.N. (2008) Reversibility of Soil Productivity Decline with Organic Matter of Differing Quality along a Degradation Gradient. Ecosystems, 11, 726-739. https://doi.org/10.1007/s10021-008-9154-Z

[121] Chan, K.Y., van Zwieten, L., Meszaros, I., Downie, A. and Joseph, S. (2008) Using Poultry Litter Biochars as Soil Amendments. Australian Journal of Soil Research, 46, 437-444. https://doi.org/10.1071/SR08036

[122] Chan, K.Y., Van Zwieten, L., Meszaros, I., Downie, A. and Joseph, S. (2007) Agronomic Values of Green Waste Biochar as a Soil Amendment. Australian Journal of Soil Research, 45, 629-634. https://doi.org/10.1071/SR07109

\section{Scientific Research Publishing}

Submit or recommend next manuscript to SCIRP and we will provide best service for you:

Accepting pre-submission inquiries through Email, Facebook, LinkedIn, Twitter, etc. A wide selection of journals (inclusive of 9 subjects, more than 200 journals)

Providing 24-hour high-quality service

User-friendly online submission system

Fair and swift peer-review system

Efficient typesetting and proofreading procedure

Display of the result of downloads and visits, as well as the number of cited articles

Maximum dissemination of your research work

Submit your manuscript at: http://papersubmission.scirp.org/

Or contact jacen@scirp.org 